\section{Physician global assessment in systemic lupus erythematosus: can we rely on its reliability?}

We read with great interest the recent paper by Aranow et al ${ }^{1}$ about the impact of laboratory results on scoring of the Physician Global Assessment (PGA) of disease activity in systemic lupus erythematosus (SLE). PGA is an important tool for assessing disease activity, response to treatment (it is a component of the Systemic Lupus Erythematosus Responder Index (SRI)-4) and remission in SLE. Importantly, monitoring of SLE through PGA has been recommended in the recent European League against Rheumatism (EULAR) guidelines. ${ }^{2}$

In their paper, ${ }^{1}$ Aranow et al found very high inter-rater PGA reliability values (pre-lab PGA intraclass correlation coefficient (ICC) 0.98; post-lab PGA ICC 0.99) based on 50 clinical vignettes. In our recent systematic review of the psychometric properties of the $\mathrm{PGA}^{3}{ }^{3}$ we show that this instrument is valid and responsive for assessing disease activity in SLE, but has a high variability. In the paper by Aranow et al, the inter-rater reliability of PGA was assessed using the ICC with a two-way random-effect model based on mean scorings (ICC 2,k). This has the effect of artificially increasing reliability estimates compared with the use of single measurement models (ICC 2,1), which would also be interesting to present.

This further suggests a major need for both standardisation and training in the scoring of this increasingly used instrument, particularly among non-expert rheumatologists, as those may wish to follow the recent EULAR recommendations for SLE. ${ }^{2}$

Elisabetta Chessa, ${ }^{1}$ Matteo Piga $\odot,{ }^{1}$ Laurent Arnaud $\odot^{2,3}$

${ }^{1}$ Rheumatology, University Clinic and University of Cagliari (CA), Cagliari, Italy 2Department of Rheumatology, Hôpitaux Universitaires de Strasbourg, Strasbourg, France

${ }^{3}$ National Reference Center for Auto-immune Diseases (RESO), Strasbourg, France

Correspondence to Professor Laurent Arnaud, Department of Rheumatology, Hôpitaux Universitaires de Strasbourg, Strasbourg 67100, France; laurent.arnaud@chru-strasbourg.fr
Contributors All authors contributed to the data analysis and preparation of the letter.

Funding The study was funded through the training Bursary Programme 2019 of the SLEuro European Lupus Society (recipient of the bursary: EC).

Competing interests None declared.

Patient and public involvement Patients and/or the public were not involved in the design, or conduct, or reporting, or dissemination plans of this research.

Patient consent for publication Not required.

Provenance and peer review Not commissioned; internally peer reviewed.

(c) Author(s) (or their employer(s)) 2020. No commercial re-use. See rights and permissions. Published by BMJ.

Check for updates

To cite Chessa E, Piga M, Arnaud L. Ann Rheum Dis Epub ahead of print: [please include Day Month Year]. doi:10.1136/annrheumdis-2020-217632

Received 18 April 2020

Accepted 18 April 2020

\section{Sinked}

https://doi.org/10.1136/annrheumdis-2020-217692

Ann Rheum Dis 2020;0:1. doi:10.1136/annrheumdis-2020-217632

ORCID iDs

Matteo Piga http://orcid.org/0000-0002-1126-8315

Laurent Arnaud http://orcid.org/0000-0002-8077-8394

\section{REFERENCES}

1 Aranow C, Askanase A, Oon S, et al. Laboratory investigation results influence physician's global assessment (PGA) of disease activity in SLE. Ann Rheum Dis 2020:annrheumdis-2019-216753.

2 Fanouriakis A, Kostopoulou M, Alunno A, et al. 2019 update of the EULAR recommendations for the management of systemic lupus erythematosus. Ann Rheum Dis 2019;78:736-45.

3 Chessa E, Piga M, Floris A, et al. Use of physician global assessment (PGA) in systemic lupus erythematosus: a systematic review of its psychometric properties. medRxiv 2020. 